\title{
Streambank Erosion Susceptibility Index and Flood-prone Area Mapping along the Karra River, Hetauda, Central Nepal Sub- Himalaya
}

\author{
${ }^{1}$ Rythum Rai, ${ }^{2}$ Naresh Kazi Tamrakar \\ ${ }^{1}$ Institute of Science Technology, Tribhuvan University, Kathmandu, Nepal; \\ ${ }^{2,3}$ Associate Professor, Dr. Naresh Kazi Tamrakar, research fields: sedimentology, engineering geology and \\ construction material engineering, Tribhuvan University, Kathmandu, Nepal;
}

Raiythumgmail.com; nkt.tamrakar@gmail.com;

\begin{abstract}
The Karra River, one of the major tributaries of the Rapati River, is the $5^{\text {th }}$ order stream that extends for about $21.91 \mathrm{~km}$ length in $92 \mathrm{sq}$. $\mathrm{km}$. of watershed area. It is situated in the southern region of the Hetauda City, which is under the rapid development as a settlement and industrial area. The Karra River area is frequently impacted by streambank erosion and flooding during the heavy rainfall in monsoon due to loosely consolidated sedimentary terrain of the Upper Siwalik Subgroup and the unconsolidated Late Quaternary Deposits, which are vulnerable to erosion. Morpho-hydraulic parameters and stream crosssectional characteristics and parameters of streambank erosion susceptibility index (SESI) rating system were assessed along the Karra River at 19 transects. The rating of the SESI are based on bank angle, bank height ratio, root depth ratio, root density, surface protection, bank materials and characteristics of stratification. The flood-prone area map was prepared based on the morpho-hydraulic parameters of the stream based on the maximum bankfull depth. The ER and W/D ratio were estimated to determine the affinity of flooding and lateral instability of the stream. Near Bank Stress Index and SESI dealt with streambank erosion potential were assessed to estimate the streambank erosion rate.
\end{abstract}

Keywords: Streambank Erosion Susceptibility Index (SESI), Near Bank Stress Index (NBSI), Entrenchment Ratio (ER), Floor-prone area, Siwalik

\section{Introduction}

The Karra River situated in the southern region of the Hetauda City between the CHuriya Range to the south and the Shikharkateri Range to the north is one of the major tributaries of the Rapati River (Fig. 1). The Hetauda City is the administrative headquarter of the Makwanpur District, Central Development Region, Nepal. It lies in the portion of the Sub-Himalaya (Siwaliks) of Central Nepal, Hetauda Dun [1].

Rapid urbanization and encroachments near the streambank can decrease the stability of streambanks and therefore increase mass wasting and stream disturbance [2]. Streambank erosion is a dynamic and natural process as streams meander across the landscape that occurs in every watershed. Generally, river flow tends to maintain a dynamic equilibrium. Sediment load and size tend to balance stream discharge and slope [3]. If any of these variables is required to maintain the balance. Any activity which affects the 
Rythum Rai, Naresh Kazi Tamrakar; Streambank Erosion Susceptibility Index and Flood-prone Area Mapping along

the Karra River, Hetauda, Central Nepal Sub-Himalaya. Transactions on Machine Learning and Artificial Intelligence, Volume 7 No 6 December (2019); pp: 11-20

balance may bring several consequences. Streambank failure can occur by several mechanisms, including cantilever failures of undercut banks, toppling of vertically arranged slabs, slumping and wedge failures [4]. The Karra River is one of the severely affected streams, and is frequently impacted due to streambank erosion and flooding during the heavy rainfall in monsoon due to loosely consolidated and unconsolidated sedimentary terrain of the Upper Siwalik Subgroup and Late Quaternary alluvial deposits [5]. Some of the major problems faced in vulnerable areas along the streambanks are flooding, streambank erosion, dilution of riparian vegetation, encroachments and expansion of settlement areas. Therefore, the present study was undertaken to prepare a flood-prone map and to assess the Streambank Erosion Susceptibility Index (SESI) and Near Bank Stress Index to prepare SESI map and to estimate annual streambank erosion rate.

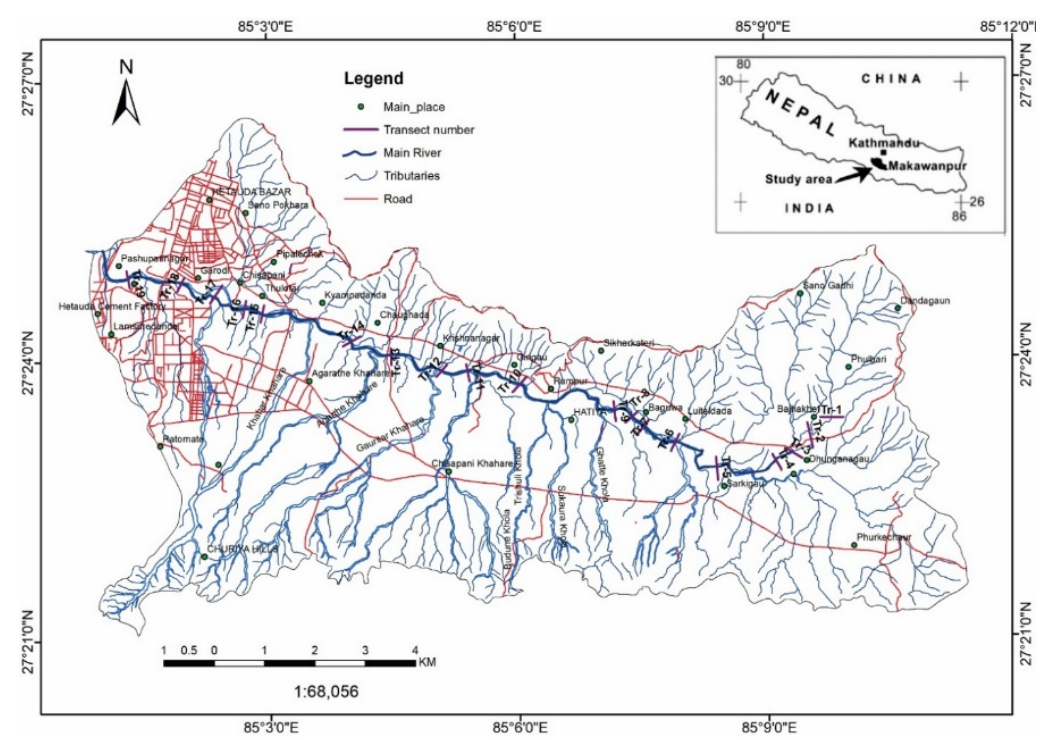

Figure 1: Location map of the study area, Karra River, Hetauda, Central Nepal.

\subsection{Drainage}

The Karra River is the $5^{\text {th }}$ order perennial stream and a major tributary of the Rapati River, and extends for about $21.91 \mathrm{~km}$ and includes $92 \mathrm{~km}^{2}$ of watershed area. It originates from the Siwalik Hills and flows E-W, forming an axial drainage system showing a trellised pattern with tributaries having dendritic patterns. The tributaries from the south of the Karra River are much wider and larger compared to those from the northern hills.

\subsection{Geology}

The Siwalik of the study area are divisible into three units the Lower Siwalik, Middle Siwalik and Upper Siwalik Subgroups based on the lithology and increasing grain size. The Lower Siwalik Subgroup comprises of alteration of brown weathered sandstone and variegated mud rocks. The Middle Siwalik Subgroup consists mainly of conglomerates [6]. The Lower and the Middle Siwalik Subgroups are distributed beneath and in the northern areas of the Karra River where they are folded, whereas the Upper Siwalik Subgroup is distributed in the southern part. Moreover, the study area also consists of the Late Quaternary deposits such as gravel, sand and mud. The Sub-Himalaya constitutes the foothills of the Himalayas and deposits of sediments of the Middle Miocene to the Early Pleistocene [7]. 


\section{Methodology}

\subsection{Survey of Stream and Flood-prone mapping}

The degree of incision involves a measurement of bank height ratio and entrenchment ratio that gives the entrenchment of each stream segments, and shows the degree of affinity of flooding. W/D ratio determines the degree of aggradation and its increase is associated with accelerated streambank erosion [8]. Morpho-hydraulic parameters were determined from cross-sectional and longitudinal surveys of streams [9]. Morpho-hydraulic parameters such as bankfull depth, width of flood-prone area, entrenchment ratio and width-depth ratio, were then computed with the help of the survey data. Stream energy slope was determined from the longitudinal survey.

Flood-prone width was measured using Rosgen system of stream classification method [10]. Nineteen transects were selected to measure the stream cross-sections. The flood-prone elevation and width were measured by identifying the bankfull stage to find the flood-prone elevation. The twice value of maximum depth from the bankfull elevation to streambed gave the flood-prone elevation which represents the water elevation approximately of 50-years discharge.

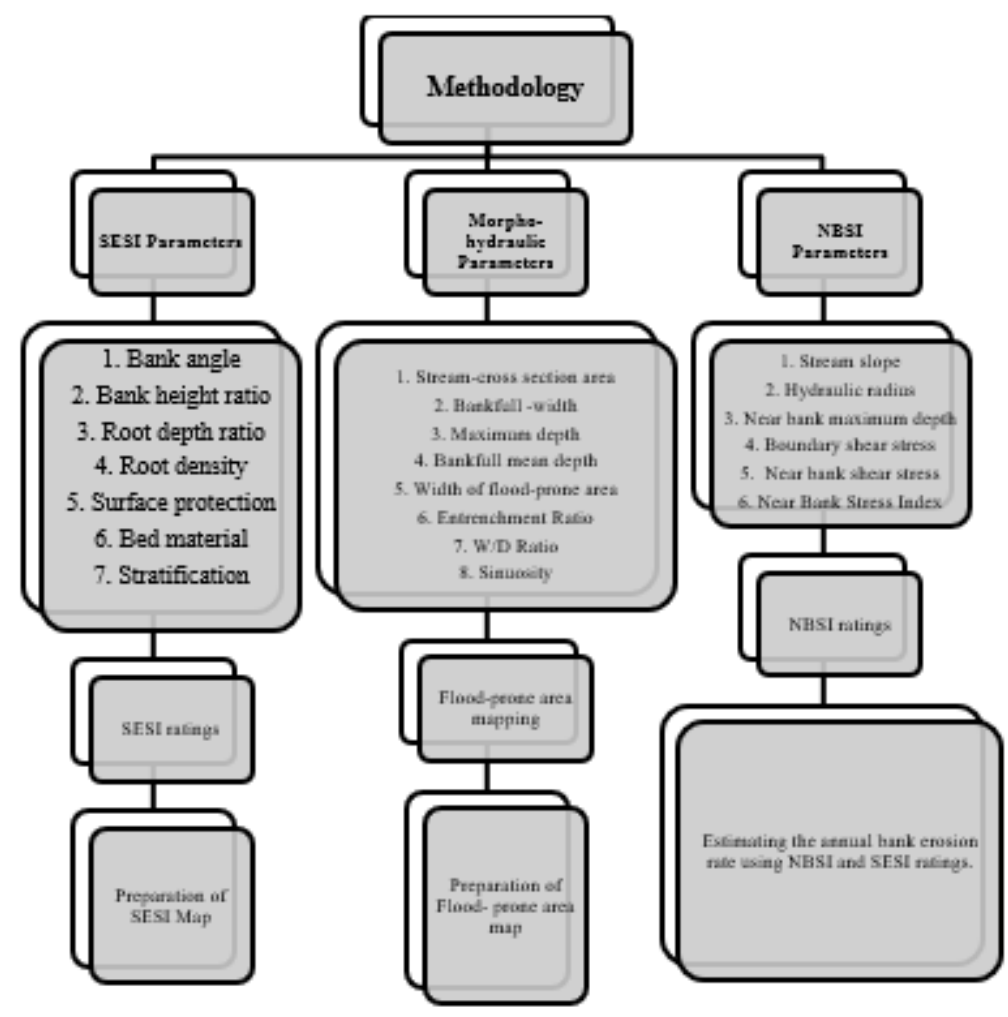

Figure 2: Flow-chart of methodology.

\subsubsection{SESI Parameters}

Rosgen [11]proposed streambank characteristics: erodibility potential (BEHI) and hydraulic forces (NBSI). The BEHI combines several streambank parameters (bankfull height, root depth and root density, surface protection and bank angle) that indicate streambank erosion whereas the NBSI that is obtained from the 
Rythum Rai, Naresh Kazi Tamrakar; Streambank Erosion Susceptibility Index and Flood-prone Area Mapping along

the Karra River, Hetauda, Central Nepal Sub-Himalaya. Transactions on Machine Learning and Artificial Intelligence, Volume 7 No 6 December (2019); pp: 11-20

ratio of near bank stress and mean boundary shear stress indicates erosivity. These parameters can be converted into the risk rating system to estimate annual streambank erodibility rate of the stream.

Six SESI parameters were assessed in the field and were scored accordingly after [11].

o Bank Height Ratio (BHR): It is the ration of bank height to bankfull height of the stream. Common bankfull indicators in stable streams include top of bank, top of point bars, change in slope and vegetation indicators.

o Root Depth Ratio (RDH): It is the ratio of average plant root depth to the bank height, expressed as percent.

0 Root Density (RD): It is expressed as a percent, the proportion of the streambank surface covered by plant roots.

o Surface Protection (SP): It is the percentage of streambank covered by plant roots, downed log, branches, rocks, etc.

o Bank Angle (BA): It is the angle of the lower bank - the bank from the waterline at base flow to the top of the bank as opposed to benches that are higher on the floodplain.

o Bed Materials: Bed materials such as bed rock, boulders, cobble, gravel, sand, silt/loam and clay gives different score. Single stratified layer has score of 5 and multiple layer gives score 10.

Finally, all these scores rated to categorize the vulnerability of streambank erosion susceptibility. The scores assigned were categorize into very low (5-9.5), low (10-19.5), moderate (20-29.5), high (30-39.5), very high (40-45) and extreme SESI (46-50) and thus, were combined for preparation of SESI map.

\subsubsection{Near Bank Stress Index (NBSI)}

For assessment of near bank stress index (NBSI), the boundary shear stress and the near bank shear stress were obtained. The bound shear stress is the stress available to transport bed loads, and is the force that entrains and moves the particles. Using the expression of Shields[12], the boundary shear stress was obtained was:

$$
\tau=\gamma \cdot \text { R.S }
$$

where, $\gamma$ is density of water $\left(1000 \mathrm{~kg} / \mathrm{m}^{3}\right), \tau$ is boundary shear stress $\left(\mathrm{N} / \mathrm{m}^{2}\right), R$ is a hydraulic radius $(\mathrm{m})$ and $S$ is channel slope $(\mathrm{m} / \mathrm{m})$. the near bank shear stress $\left(\tau_{n b}\right)$ of channel was obtained by using the expression of Leopold [10] and Rosgen [11], as

$$
\tau_{n b}=\gamma \cdot D_{n b} \cdot S_{n b}
$$

where, $\gamma$ is the unit weight of water $\left(998 \mathrm{~kg} / \mathrm{m}^{3}\right), D_{n b}$ is the near bank maximum depth and $S_{n b}$ is the near bank channel slope.

The NBSI was obtained from the ratio of near bank shear stress to the boundary shear stress, and was converted to score rating system to categorize vulnerability of streambank erosion as very low (near bank stress rating 1: when NBSI <0.8), low, 2 (NBSI $0.8-1.05$ ), moderate, 3 (NBSI $1.06-1.14$ ), high, 4 (1.15 1.19), very high $(1.20-1.60)$ and extreme, 6 (NBSI > 1.6). The streambank erosion rates were predicted for all transects with respect to NBSI and SESI from the standard graph. 


\section{Results}

\subsection{ER and $W / D$ ratio}

A stream becomes entrenched if the value of ER is less than 1.4, if the value lies 1.4 to 2.2 it is considered as moderately entrenched but if higher than 2.2, the stream shows affinity of flooding.the highest entrenchment value is obtained in Pashupatinagar transect, 10.44 (Table 1), which indicates that the stream is slightly entrenched and has possibility of flooding. Similarly, the Bajhakhet - A and Sarkigau - A transects are moderately entrenched and has possibility of flooding. The ER $=1.3$ value of only Girigau transect shows the stream to be entrenched while remaining all transects have higher value than 1.4 , thus showing affinity of flooding.

W/D ratio gives the rapid visual assessment of channel stability as the wide channels are produced by lateral erosion. W/D ratio of the Karra River varies widely 6.51 to 77.62, indicating low to high W/D ratio (Table 1). The highest W/D ratio has been obtained in Chisapani, Kyampadada and Gardoi that exceeds more than 40 which are $77.62,75.04$ and 64.66 respectively.

\subsection{Flood-prone map}

Flood-prone width ranges from 94.9 (Sarkigau - B) to $339.5 \mathrm{~m}$ (Pashupatinagar) as shown in Table 1. The transects from the Bajhakhet to Sarkigau - B of the upstream transects have narrow flood-prone width. The flood-prone widths are much wider on the downstream transects compared to the upstream transects Sarkigau - B. Rampur area one of the active settlement areas lies in flood-prone. The Chaughada, Kyampadada, Gardoi and Pashupatinagar segments show agricultural, settlement, transportation and industrial areas under the most flood affected zones. The Girigau, Rampur, Luiteldada and the Baguwa areas reveal their agricultural lands to be mostly affected by floods.

Table 1: Morpho-hydraulic Parameters of 19 transects of the Karra River, Hetauda, Central Nepal.

\begin{tabular}{|c|c|c|c|c|c|c|c|c|}
\hline Location & Transect no & $\begin{array}{l}\text { Bankfull } \\
\text { cross- } \\
\text { section } \\
\text { area, } \\
\text { A bkf }\left(\mathrm{m}^{2}\right)\end{array}$ & $\begin{array}{c}\text { Bankfull } \\
\text { width, } W_{\text {bkf }} \\
\text { (m) }\end{array}$ & $\begin{array}{l}\text { Width } \\
\text { flood- } \\
\text { prone } \\
\text { area, } W_{\text {fpa }} \\
\text { (m) }\end{array}$ & $\begin{array}{c}\text { Max. } \\
\text { bankfull } \\
\text { depth, } D_{\max } \\
\text { (m) }\end{array}$ & $\begin{array}{c}\text { Mean } \\
\text { depth at } \\
\text { bankfull, } \\
D_{\text {bkf }}= \\
\text { Abkf }_{\text {b }} \text { Wkf }_{\text {bkf }} \\
\text { (m) }\end{array}$ & $\begin{array}{c}\text { Entrenchment } \\
\text { ratio, } E R= \\
W_{\text {fpa }} / W_{\text {bkf }}\end{array}$ & $\begin{array}{c}\text { Width-depth } \\
\text { ratio } W / D= \\
W_{b k f} / D_{b k f}\end{array}$ \\
\hline Bajhakhet-A & Tr-1 & 2.85 & 4.3 & 8.3 & 0.8 & 0.66 & $1.93(\mathrm{M})$ & $6.51(\mathrm{~L})$ \\
\hline Bajhakhet - B & $\operatorname{Tr}-2$ & 11.33 & 13 & 39 & 2.72 & 0.87 & 3.00 (S) & $14.9(\mathrm{M})$ \\
\hline Dhunganagau & $\operatorname{Tr}-3$ & 8.4 & 10 & 23.5 & 1.45 & 0.84 & $2.35(\mathrm{~S})$ & $11.9(\mathrm{VL})$ \\
\hline Sarkigau - A & $\operatorname{Tr}-4$ & 9.2 & 9.5 & 15.5 & 1.34 & 0.96 & $1.63(\mathrm{M})$ & 9.89 (M) \\
\hline Sarkigau - B & $\operatorname{Tr}-5$ & 20.41 & 11.9 & 94.9 & 1.76 & 1.71 & 7.97 (S) & $6.95(\mathrm{VL})$ \\
\hline Luiteldada & $\operatorname{Tr}-6$ & 27.11 & 24 & 132 & 2.02 & 1.12 & $5.79(\mathrm{~S})$ & $21.42(H)$ \\
\hline Baguwa - A & $\operatorname{Tr}-7$ & 24.71 & 25 & 247 & 1.56 & 0.98 & $9.88(S)$ & $25.51(\mathrm{H})$ \\
\hline Baguwa - B & $\operatorname{Tr}-8$ & 17.93 & 21 & 141 & 1.65 & 0.85 & $6.71(\mathrm{~S})$ & $24.7(\mathrm{H})$ \\
\hline Baguwa - C & Tr-9 & 15.2 & 22 & 169 & 1.56 & 0.69 & 7.68 (S) & $31.88(H)$ \\
\hline Girigau & $\operatorname{Tr}-10$ & 17.3 & 16.5 & 22.2 & 2.8 & 1.04 & $1.35(E)$ & $15.86(\mathrm{M})$ \\
\hline Rampur & $\operatorname{Tr}-11$ & 26.93 & 21 & 163 & 1.92 & 1.28 & 7.76 (S) & $16.4(\mathrm{M})$ \\
\hline Krishnanagar-A & $\operatorname{Tr}-12$ & 17.7 & 15.6 & 80.6 & 1.9 & 1.13 & $5.16(S)$ & $13.8(\mathrm{M})$ \\
\hline Krishnanagar-B & $\operatorname{Tr}-13$ & 72.8 & 38 & 162 & 3.1 & 1.91 & $4.26(S)$ & $19.89(\mathrm{M})$ \\
\hline Chaughada & $\operatorname{Tr}-14$ & 12.5 & 16.5 & 150 & 2.1 & 0.75 & 9.09 (S) & $22.00(\mathrm{H})$ \\
\hline Kyampadada & $\operatorname{Tr}-15$ & 15.3 & 32 & 225 & 2.1 & 0.41 & 7.03 (S) & 75.04 (VH) \\
\hline Thulotar & $\operatorname{Tr}-16$ & 49.36 & 37.8 & 194.8 & 1.82 & 1.3 & $5.15(S)$ & $29.07(H)$ \\
\hline Chisapani & $\operatorname{Tr}-17$ & 10.1 & 28 & 260.75 & 0.79 & 0.36 & 9.31 (S) & 77.62 (VH) \\
\hline Gardoi & $\operatorname{Tr}-18$ & 36.46 & 48.5 & 113.5 & 2.69 & 0.75 & $2.34(S)$ & 64.66 (VH) \\
\hline Pashupatinagar & Tr-19 & 28.8 & 32.5 & 339.5 & 1.17 & 0.88 & $10.44(\mathrm{~S})$ & $36.93(\mathrm{H})$ \\
\hline
\end{tabular}

E-Entrenched, M-Moderately entrenched, S-Slightly entrenched, VL-Very low, L-Low, M-Medium and H-High, VH-Very high 


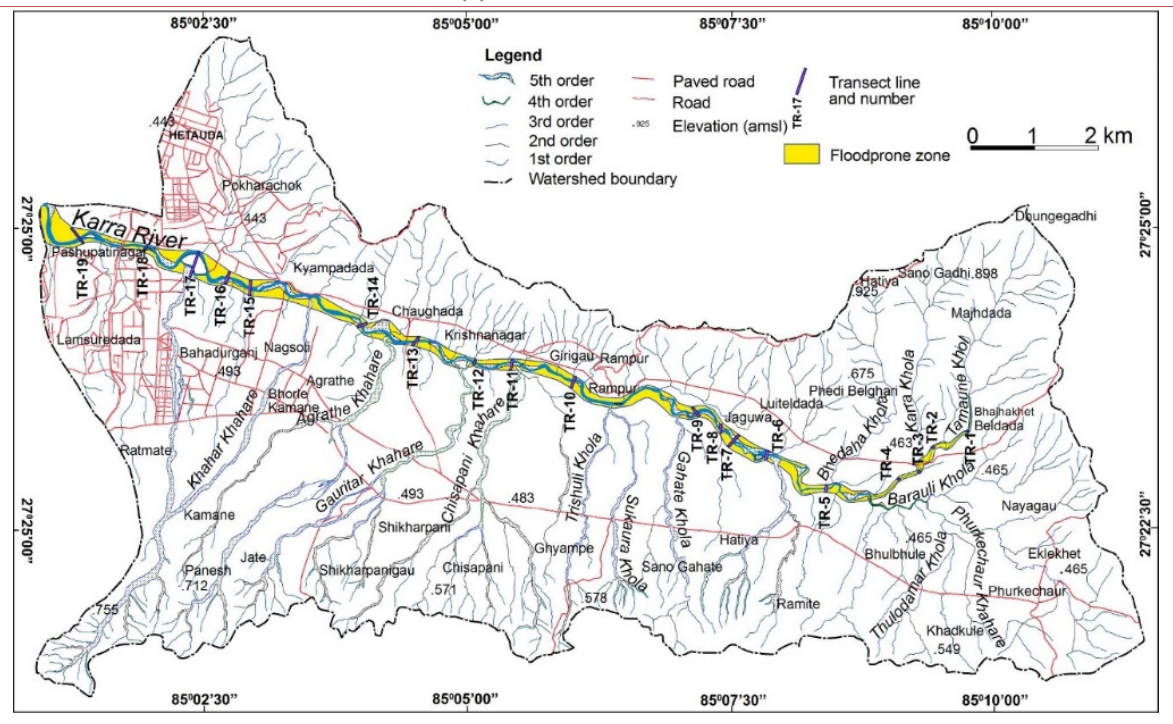

Figure 3: Flood-prone map of the Karra River, Hetauda, Central Nepal.

\subsection{Streambank Erosion Susceptibility Index (SESI)}

The SESI parameters were scored based on bank angle, bank height ratio, root depth ratio, root density, surface protection, bank material and their stratification. The SESI rating of river shows that all the three transects of Baguwa and Gardoi are rated as extremely susceptible transects, which have scores high than 45 (Table 3). The upstream transects are rated as low susceptible transects. The rate of susceptibility gradually increases towards the downstream transects (Table 4; Fig. 4).

Among 19 transects of the river,the three transects of upstream from Bajhakhet to Dhunganagau has been rated as low SESI due to the low bank angle and presence of clayey sediments, which have high cohesive force. Similarly, the Krishnanagar - B (Tr-13) and Kyampadada (Tr-15) are rated as moderately susceptible for streambank erosion which consists of single layer of clay and gravel sediment respectively. Although, these transects have low bank angle and moderately protected surface but also consist large difference in bank height ratio, low root depth ratio and root density. Sarkigau - A, Thulotar, Chisapani and Pashupatinagar have been estimated as high SESI rating. Mostly, these transects consists of low bank height ratio, low root depth ratio and single layer of sand in bank which leads to high rate of bank erosion but Krishnanagar - A (Tr-14) is rated high SESI due to low root density, surface protection and high bank height ratio and has very high bank angle $\left(129^{\circ}\right)$ due to souring. Similarly, the Sarkigau - B (Tr-5), Luiteldada (Tr-6), Girigau (10), Rampur (Tr-11) and Chaughada (Tr-14) has low root depth ratio, single layer of sand streambank sediment with high bank height ratio exhibits these zone as very highly susceptible than previous transects. In comparison among all transects, Baguwa (Tr-7, Tr-8 and Tr-9) and Gardoi (Tr18) are extremely susceptible for streambank erosion. Although these area has moderate surface protection but the parameters such as bank height ratio and bank angle are very high whereas the root depth ratio is very low. Moreover, all transects of Baguwa ( $\mathrm{Tr}-7$ and $\mathrm{Tr}-8$ ) comprises of double stratification of dominantly gravel sediment and slight amount sands which has very low cohesive force and can be easily erode when the root depth ratio is very low in high bank height ratio and high bank angle. 


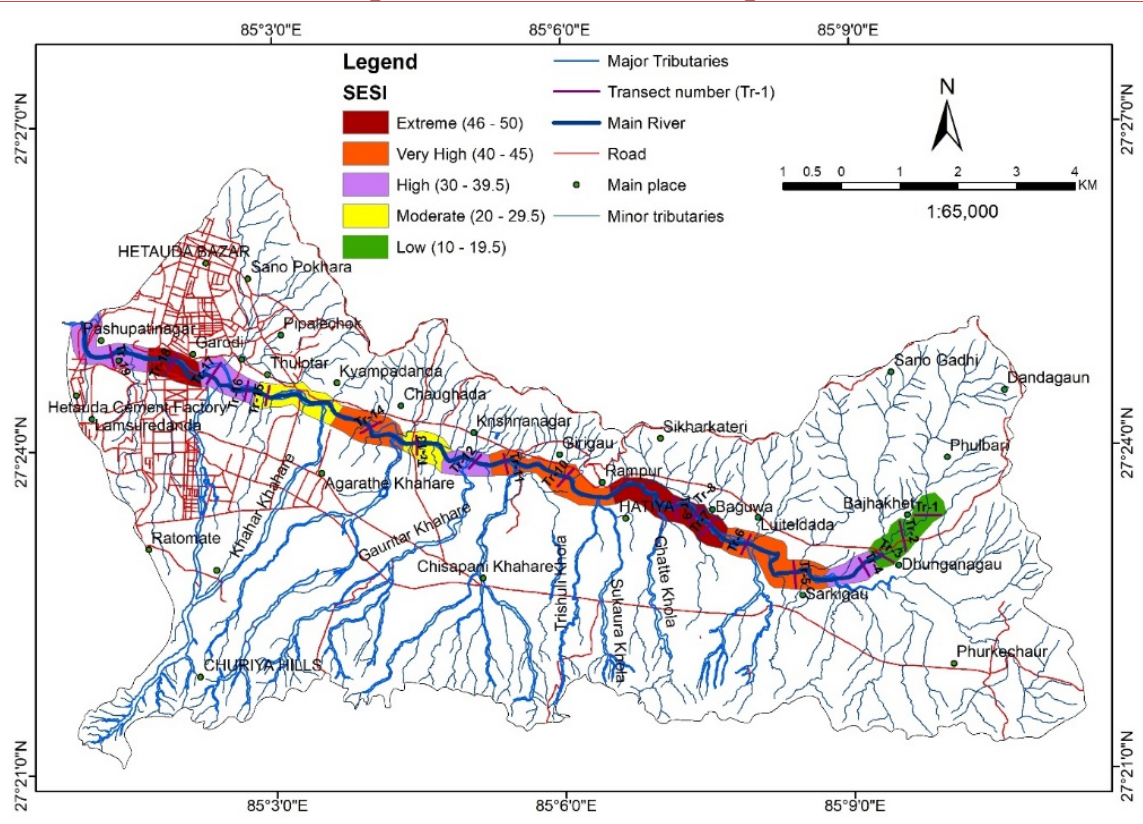

Figure 4: SESI map of the Karra River, Hetauda, Central Nepal.

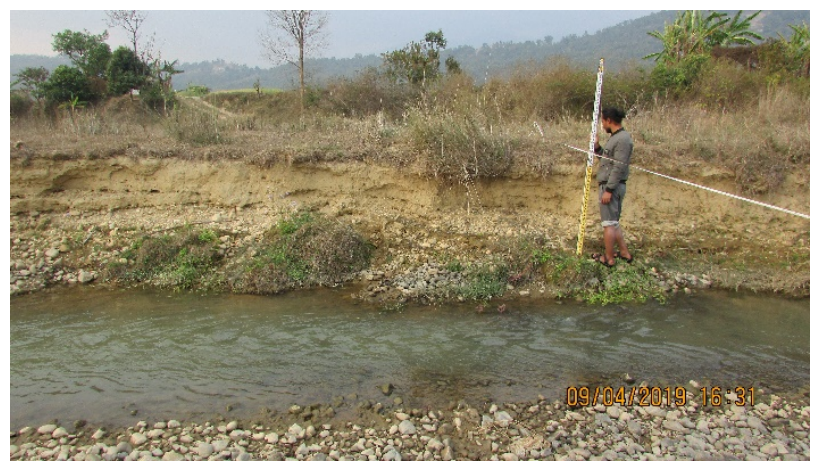

Figure 5: Extreme SESI ovserved on Baguwa - C transect along the Karra River.

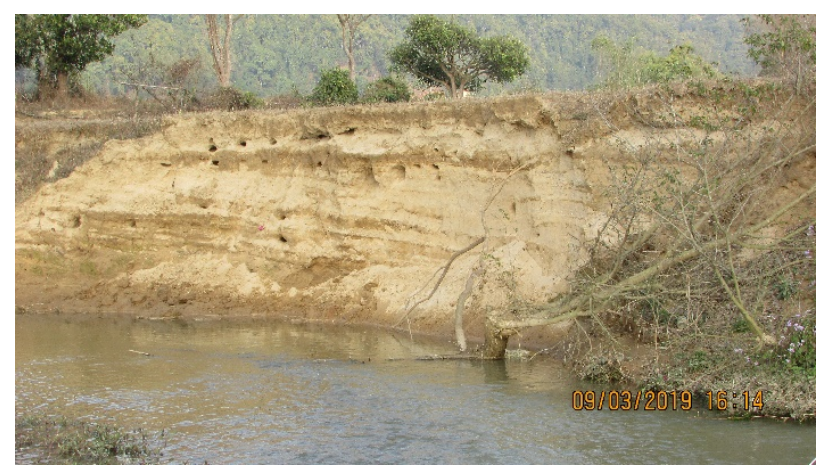

Figure 6: Very HIgh SESI observed on the Krishnanagar A along the Karra RIver.

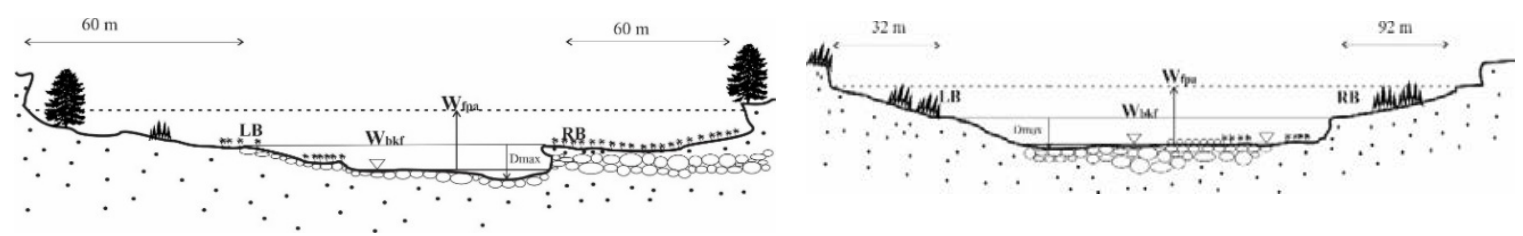

Figure 7: Stream cross-section of Baguwa- C transect, Tr-8 and Krishnanagar - A transect, Tr-12 of the Karra River.

\subsection{Near Bank Stress Parameters}

\subsubsection{Near Bank Maximum Depth}

It determines the maximum depth of the near streambank transect during the survey of stream crosssection. To calculate the near bank shear stress, the maximum depth $\left(D_{n b}\right)$ was measured at one-third portion of near streambank transect or cross-section. It is directly proportional to the near bank shear stress [8]. 
Rythum Rai, Naresh Kazi Tamrakar; Streambank Erosion Susceptibility Index and Flood-prone Area Mapping along

the Karra River, Hetauda, Central Nepal Sub-Himalaya. Transactions on Machine Learning and Artificial Intelligence, Volume 7 No 6 December (2019); pp: 11-20

\subsubsection{Hydraulic Radius}

The hydraulic radius $(R)$ is hydro-morphologic parameter which controls water discharge and defined based on the shear stress at boundary as the ratio of the channel's cross-sectional area of the flow to its wetted perimeter[14]. The wet portion of the stream cross-section's perimeter is known as wetted perimeter. A river with a larger hydraulic radius indicates higher velocity and larger stream cross-sectional area which means the greater the hydraulic radius, the larger volume of water the channel can carry.

\subsubsection{Stream Slope}

Stream slope is the dimensionless longitudinal profile of hydraulic slope of stream which determines degree of the water surface elevation and denoted by ' $\mathrm{S}_{\mathrm{nb}}$ '. To calculate boundary shear stress, it is denoted by ' $S$ '. Stream slope plays vital role and varies the velocity of the stream flow. As the stream slope increase the near bank shear stress also increases.

The NBS ranges from 452.31 to $3.91 \mathrm{~Pa}$ (Table 4). Bajhakhet section (Tr-1) has highest amount of stress (329.54 pa.) due to high stream slope. Overall, the mean boundary shear stress of the stream is $79.37 \mathrm{~Pa}$ (Table 4). Generally, the near bank stress index (NBSI) dominates low to extreme score 4.25 to 0.75 . Most of the study sites are categorized into high, very high and extreme rating excluding Krishnanagar - A, Luiteldada and Sarkigau - B.

\subsection{Streambank Erosion Rate}

The streambank erosion rate has been predicted in all transects with respect to NBSI and SESI which ranges from 0.03 to 4.87 meter per year (Fig. 3). All the three transects of Baguwa and Gardoi have very high amount of predicted annual bank erosion rate that ranges from 1.82 to 4.87 meter per year.

Similarly, the correlation between the NBSI and W/D ratio shows the value $R^{2}=0.7072$ (Fig. 8). W/D ratio increases gradually from upstream to downstream. As the ratio increases, the hydraulic against the banks also increases and erosion is accelerated.

\section{Conclusion}

The flood-prone width ranges from 94.9 to $339.5 \mathrm{~m}$ and is narrow in the upstream transects Sarkigau - B and becomes wider downstream. The ER shows the degree of affinity of flooding of the stream. Baguwa - $C$ is entrenched. Bajhakhet - A and Sarkigau - A transects are moderately entrenched while remaining all transects are non-entrenched and show affinity of flooding. The W/D ratio when increases from the upstream to the downstream segments shows affinity of lateral erosion of streambank.

The extremely susceptible transects to streambank erosion are identified as Baguwa - A, Baguwa -B, Baguwa - C and Gardoi. Other transects are very high to low susceptible to streambank erosion. the study area seems to be frequently impacted due to the streambank erosion and flooding during the heavy rainfall in monsoon as the area is mainly composed of loose unconsolidated sedimentary terrain, which are vulnerable to streambank erosion are steep banks, poor vegetation and loose bank materials.

The good relation between NBSI and W/D ratio suggest that with increased W/D ratio with the increase of discharge, the near bank stress index tends to increase, thus aggravating streambank erosion. The streambank erosion rates have been estimated to be $0.03-4.87$ meter per year for the Karra River. 
It is recommended to relocate schools, and high priority settlement areas from the flood-prone zone and to protect the stream segments of high to extreme SESI using bio-engineering methods. The Government should organize the mitigative programs for flooding and streambank erosion problems immediately before.

\section{Acknowledgments}

Authors are thankful to the Central Department of Geology, Tribhuvan University for providing facility of field equipment. Authors thank Ananta Joshi and Suman Maharjan for their assistance during the field survey, and Raj Kumar Ghising for providing financial support.

\section{REFERENCES}

[1]. Auden, J.B., et al., Traverse in the Himalaya, Record of Geological Survery of India, 1935. v.69(2), p. 123-167

[2]. Jacobson, R.B., and A.T. Primm, et al., Historical land-use changes and potential effects on stream disturbance in the Ozark Plateaus, Missouri, 1997. USGS Water-Supply Paper 2484. Denver, Colorado, U.S. Geological Survey, 1997.

[3]. Lane, E. W., et al., The importance of fluvial geomorphology in hydraulic engineering. Proc ASCE 81(745): p. 1-17.

[4]. Thorne, C.R., et al., Processes and Mechanisms of River Bank Erosion, in Gravel-Bed Rivers: Fluvial Process, Engineering and Management, R.D. Hey, J.C. and C.R. Thorne edited by Wileyand and Sons, Chichester, England, 1982, p. 227-221.

[5]. Tamrakar, N. K. and Karki, B., et al., Geomorphometric properties and varaibility of sediment delivery ratio and specific sediment yield among sub-basins of the Karra River, Hetauda, central Nepal Sub-Himalaya, Journal of Nepal Geological Society, 2019. v. 59, p. 19-37.

[6]. Tokuoka, T., Takayasu, M. Yoshida and K. Hisatomi, et al., The Churia (Siwalik) Group of the Arung Khola area, West Central Nepal. Mem. Fac. Sci., Shimane Univ., 20: 135-210. West, R.M., and Munthe, J. 1981 Cenozoic vertebrate palaeontology and stratigraphy of Nepal. Himalaya Geology. 1986. v. 11., p. 18-27

[7]. Gautam, P. and Rösler, W., et al., Depositional chronology and fabric of Siwalik Group sediments in Central Nepal from magentostratigraphy and magnetic anisotropy. Journal of Asian Earth Sciences. 1999. v. 17, issue 5-6, p. 659-682.

[8]. Rosgen, D. L., et al., A stream Channel Stability Assessment Methodology. Federal Interagency Sediment Conference. 2001, March 25-29, Reno, Nevada, p. 18-26.

[9]. Rosgen, D. L., et al., Applied River Morphology. Wildland Hydrology Books, edited by Pagosa springs, Colorado. 1996. P. 6-42.

[10]. Rosgen, D.L., et al., Stream Classification using the Rosgen System. Stream Classification using the Rosgen System. Companion Document, EFH Notice 210-WI-119 February 2009.

[11]. Rosgen, D. L., et al., A Practical Method of Computing Streambank Erosion Rate. Proceedings of Seventh Federal Interagency Sediment Conference 2001 March 24-29, Reno, Nevada, p. 9-17. 
Rythum Rai, Naresh Kazi Tamrakar; Streambank Erosion Susceptibility Index and Flood-prone Area Mapping along the Karra River, Hetauda, Central Nepal Sub-Himalaya. Transactions on Machine Learning and Artificial Intelligence, Volume 7 No 6 December (2019); pp: 11-20

[12]. Shields, A., et al., Application of similarity priciples and turbulent research to bed-load movement. In: W.P. Ottand J.C. Uchelen (translators), Mitt. Preuss, Verschsanst, Berlin. Wasserbau Schifbau, California Institute of Technology, Pasadena, 1936. CA, Report No. 167, p. 143.

[13]. Leopold, L.B., Wolman G.M., and Miller J.P., et al., Fluvial Process in Geomorphology. W.H. Freeman and Co. San Fracisco, 1964, p. 522.

[14]. Doll, B.A., G.L. Grabow, K.R., J. Halley, W.A. Harman, G.D. Jennings and D.E. Wise, et al., Stream Restoration: A Natural Channel Desighn Handbook. North Carolina Stream Restoration Institute, North Carolina State University and North Carolina Sea Grant. 2003. 128p. 